\title{
Growth, Nutrient Uptake and Seed Cotton Yield As Influenced By Split Application of Nutrients through Fertigation in Bt Cotton
}

\author{
Sanjay Kakade*, Vilas Bhale, Jayant Deshmukh and Sudhir Wadatkar \\ Department of Agronomy, Dr. Panjabrao Deshmukh Krishi Vidyapeeth, \\ Akola - 444104(M.S), India \\ *Corresponding author
}

\begin{tabular}{|c|c|}
\hline & A B S T R A C T \\
\hline & $\begin{array}{l}\text { A field experiment was conducted during the year } 2011-12 \text { and } 2012-2013 \text { at Department } \\
\text { of Agronomy, Dr. Panjabrao Deshmukh Krishi Vidyapeeth, Akola to study the effect of } \\
\text { split application of } \mathrm{N} \text { and } \mathrm{K} \text { fertilizers on growth, yield attributes, nutrient uptake and to } \\
\text { economize the fertilizer requirement of Bt cotton under fertigation. The experiment was } \\
\text { laid out in randomized block design with four replications and five treatments imposed } \\
\text { having four different levels of drip fertigation in five splits at } 50 \text { per cent, } 75 \text { per cent, } 100 \\
\text { per cent and } 125 \text { per cent of recommended dose of } \mathrm{N} \text { and } \mathrm{K} \text { given through fertigation and }\end{array}$ \\
\hline $\begin{array}{l}\text { Ke y w o r d s } \\
\text { Cotton, Fertigation, } \\
\text { Splits, RDNK, } \\
\text { Nutrient Uptake. }\end{array}$ & $\begin{array}{l}\mathrm{P} \text { as basal compared with } 100 \text { per cent soil application of fertilizers. The results revealed } \\
\text { that, all the growth parameters viz. plant height, leaf area index, dry matter accumulation } \\
\text { per plant, root dry weight, yield attributes viz. sympodial branches, bolls picked and seed } \\
\text { cotton yield were substantially enhanced by drip fertigation level at } 125 \text { per cent } \\
\text { recommended dose of } \mathrm{N} \text { and } \mathrm{K} \text { than lower fertigation levels }(50,75 \text { and } 100 \text { per cent) and }\end{array}$ \\
\hline Article Info & over conventional soil application with 100 per cent $\mathrm{RDNK} \mathrm{Kg} \mathrm{ha} \mathrm{a}^{-1}$. Drip fertigation at \\
\hline $\begin{array}{l}\text { Accepted: } \\
\text { 28 August } 2017 \\
\text { Available Online: } \\
10 \text { September } 2017\end{array}$ & $\begin{array}{l}\mathrm{Kg}^{-1} \mathrm{r}^{-1} \text { during } 2011-12 \text { and } 2012-13 \text { respectively. Drip fertigation at } 75 \text { per cent RDNK } \\
\text { ha }^{-1} \text { recorded comparable yield with } 100 \text { per cent recommended dose of fertilizers applied } \\
\text { through soil by conventional method during both the years of study indicating } 25 \text { per cent } \\
\text { fertilizer saving through fertigation when compared to conventional soil application of }\end{array}$ \\
\hline & $\begin{array}{l}\text { fertilizers. The nutrient uptake was favourably increased with higher level of fertigation } \\
\text { compared with lower levels and soil application method. At all the stages of crop growth, } \\
\text { higher uptake of } \mathrm{N}, \mathrm{P} \text { and } \mathrm{K} \text { were observed at } 125 \text { per cent levels of } \mathrm{N} \text { and } \mathrm{K} \text { fertigation. } \\
\text { Progressive increase in applied level of } \mathrm{N} \text { and } \mathrm{K} \text { correspondingly increased the nutrient } \\
\text { uptake and lower uptake was noticed at lower level of fertigation ( } 50 \text { per cent) at all the } \\
\text { stages during both years of study. }\end{array}$ \\
\hline
\end{tabular}

\section{Introduction}

Cotton (Gossypiumhirsutum L.) is the most important commercial fiber crop of India and it is grown in about 9.59 million hectares under diverse agro climatic conditions as a white gold and king of fiber and also aptly called as "white gold". However, in India the productivity of cotton is as low as $505 \mathrm{Kg}$ lint $\mathrm{ha}^{-1}$ as compared to global average of $735 \mathrm{Kg}$ lint $\mathrm{ha}^{-1}$ (Nasarabad et al., 2013). Release of Bt cotton hybrids for commercial cultivation in India has been a historical event in increasing the productivity of cotton. Bt cotton hybrids now constitute about 90 per cent of the cotton area sown in the country. 
Maharashtra is the leading state in respect of area (41.46 lakh hectare) under cotton cultivation, which shares 35.21 per cent of total cotton growing area of the country (117.73 lakh hectare) but ranks third in production and $10^{\text {th }}$ in productivity $(303 \mathrm{~kg}$ $\mathrm{ha}^{-1}$ ) (Cotton Advisory Board Report, 2013). The obvious reasons for low productivity of cotton can be attributed to large area ( $>90$ per cent) under rainfed conditions, use of suboptimum doses of fertilizers, application of nutrients and irrigation water at improper stages of crop growth as well as the imbalanced plant nutrition. To overcome these problems, it is imperative to apply optimum doses of nutrients with judicious use of irrigation water at proper crop growth stages. Water and fertilizers are the most important critical inputs for producing vigorous healthy plants and improving the yield of cotton crop.

Among the different strategies of increasing the productivity and water and nutrient use efficiency, drip irrigation and split application of nutrients through fertigation method gaining the importance nowadays. Drip fertigation provides an efficient method of fertilizer delivery and the availability of soil moisture and nutrients at root zone of the crops influences the uptake and yield of the crop with minimum losses of nutrients through volatilization, leaching and fixation in the soil.

Bt cotton being highly exhaustive crop with regard to plant nutrients, fairly large quantities of nutrients are required (Satyanarayana Rao and Setty, 2002). Among the many strategies to improve the cotton productivity, split application of fertilizers especially nitrogen and potassium has proven more productive and profitable (Mahmood-ulHasan et al., 2003). Nitrogen and potassium fertilizers are water soluble and play a major role in the growth and development of Cotton.
The efficient use of nitrogen could be brought about by minimizing the losses that occur in the field. In addition to nitrogen, the single most important plant nutrients potash, a nutrient considered adequate in soils all over the world, has now been reported to be deficit in vast areas in recent years. This necessitates the addition of potassium based on the crop need and drip fertigation is a viable option for balanced use of this quality element. With the introduction of higher fertilizer responsive $\mathrm{Bt}$ cotton hybrids, it is necessary to increase the water and nutrient use efficiency through improved irrigation and nutrient application methods for sustainable cotton production. In drip fertigation, the roots are developed extensively in a restricted volume of soil wetted by drip fertigation. Thus, drip fertigation system can place nutrients efficiently in wetted zone and are used by the plant from soil easily which helps in achieving the higher yield of Bt cotton. In view of the above, it was felt appropriate to study the effect of split application of nutrients on growth, yield and nutrient uptake in Bt cotton.

\section{Materials and Methods}

A field experiment was conducted during 2011-12 and 2012-13 at Department of Agronomy, Dr. Panjabrao Deshmukh Krishi Vidyapeeth, Akola (M.S.) to study the effect of split application of $\mathrm{N}$ and $\mathrm{K}$ fertilizers on growth, yield attributes and nutrients uptake by crop and to economize the fertilizer requirement for Bt cotton (Var. ACH-155) under fertigation. The experiment was laid out in randomized block design with four replications. There were five treatments having four different levels of drip fertigation in five splits at 50 per cent, 75 per cent, 100 per cent and 125 per cent of recommended dose of $\mathrm{N}$ and $\mathrm{K}$ of fertilizers given through fertigation and $\mathrm{P}$ as basal compared with 100 per cent soil application of fertilizers. 
The soil of experimental plot was clayey in texture, low in organic carbon, slightly alkaline in reaction, low in available nitrogen and phosphorus and fairly high in available potassium. The soil had 32.96 per cent moisture at field capacity and 16.40 per cent at permanent wilting point with a bulk density of $1.21 \mathrm{~g} \mathrm{cc}^{-1}$.Cropping history of the experimental plot was almost practically uniform before conducting the experiment. Total rainfall during crop growth period was $481.3 \mathrm{~mm}$ in 36 rainy days during the year 2011-12 and it was $722.5 \mathrm{~mm}$ in 56 rainy days during the second year of study (201213).The experimental site was established with inline drip irrigation system $(16 \mathrm{~mm})$ with emitters of $4 \mathrm{lph}$ capacity lateral laid out at $120 \mathrm{~cm}$ with $60 \mathrm{~cm}$ dripper spacing. The average emission uniformity of drip irrigation system was estimated as 91 per cent for all the treatments. The recommended dose of fertilizers $(\mathrm{N} \& \mathrm{~K})$ was applied as per the treatments through fertigation tank of 90 lit. Capacity. Phosphorus (50 $\mathrm{Kgha}^{-1}$ ) was applied as basal and $\mathrm{N}$ and $\mathrm{K}$ as urea and murate of potash respectively through drip irrigation in five splits as per the treatments and growth stages of cotton (10\% at basal, 20 $\%$ at $20 \mathrm{DAS}, 25 \%$ at $40 \mathrm{DAS}, 25 \%$ at 60 DAS and $20 \%$ at 80 DAS.) In conventional soil application method, half nitrogen and full dose of $\mathrm{P}$ and $\mathrm{K}$ were applied as basal at sowing and remaining half dose of $\mathrm{N}$ was top dressed at 30 DAS and 60 DAS. Irrigation water was applied through drip irrigation on alternate day at the rate of 100 per cent crop evapotranspiration level. The total water used by cotton through drip (including effective rainfall) was $469.32 \mathrm{~mm}$ and $622.3 \mathrm{~mm}$ during the year 2011-12 and 2012-13 respectively. The $\mathrm{Bt}$ cotton variety $\mathrm{MRC}$ 7326 was used for experimentation. The recommended dose of fertilizers was 100:50:50 NPK Kg ha ${ }^{-1}$.Immediately after sowing, irrigation was given upto soaking of entire bed and subsequent irrigations were scheduled once in two days. For drip fertigation system the operating pressure was maintained at $1.0 \mathrm{~kg} \mathrm{~cm}^{2}$. Drip irrigation was given as per the schedule once in two days based on cumulative pan evaporation. The volume of irrigation water to be applied per plant was determined by the following formula.

$\mathrm{V}(\mathrm{lpd})=($ ETo $\times \mathrm{Kc} \times \mathrm{A} \times \mathrm{Wp})-(\mathrm{RE})$

Where,

V - Volume of water applied (liter/day/plant)

ETo - Reference evapotranspiration ( $\mathrm{mm} /$ day)

Kc - Crop factor

A - Area under crop $\left(\mathrm{m}^{2}\right)$ (Plant to plant spacing) $\mathrm{x}$ (Row to row spacing)

Wp - Wetted area fraction

$\mathrm{RE}$ - Effective rainfall in $\mathrm{mm}$

The net depth of water to be applied in drip irrigation of alternate day was determined by the following formula-

$\mathrm{D}=(\mathrm{ETo} \times \mathrm{Kc})-\mathrm{RE}$

Where,

D - Net depth of water to be required (mm)

ETo - Reference evapotranspiration ( $\mathrm{mm} /$ day)

$\mathrm{RE}$ - Effective rainfall (mm)

For cotton $\mathrm{Kc}$ values were $0.45,0.75,1.15$ and 0.70 for seedling (0-25 DAS), crop development stage (26-70 DAS), boll development (71-120 DAS) and maturity stage (>121 DAS) respectively as per FAO Irrigation Water Management Training 
Manual No.3 (1986).Based on the above formula quantity of water was calculated on alternate days and irrigation was scheduled. Time of irrigation was decided as per the discharge of water per dripper and number of drippers.

\section{Results and Discussion}

The results of the present study as well as relevant discussion have been summarized under following heads:

\section{Growth parameters}

Pooled mean of two Years (Table 1) revealed that concomitant increase in all the growth attributes were noticed with each increasing level of drip fertigation of recommended dose of $\mathrm{N}$ and $\mathrm{K}$ from 50 to 125 per cent. In cotton, among the drip fertigation levels drip fertigation at 125 per cent recommended dose of $\mathrm{N}$ and $\mathrm{K}$ ( $\mathrm{P}$ as basal) significantly improved the plant height, dry matter accumulation per plant and sympodial branches at harvest. Drip fertigation of $\mathrm{N}$ and $\mathrm{K}$ fertilizers with higher levels of 125 per cent RDNK ha ${ }^{-1}$ registered their superiority in enhancing all the growth attributes over lower fertigation levels (50, 75 and 100 per cent) and over conventional method of soil application with 100 per cent recommended dose of NPK Kg ha ${ }^{-1}$.However the plant height at 100 per cent $\mathrm{N}$ and $\mathrm{K}$ through soil application $\left(\mathrm{T}_{1}\right)$ was found comparable with 75 per cent drip fertigation. The plants were taller when the fertilizers were applied through drip fertigation in split doses as compared to soil application of fertilizers. Higher frequency of irrigation and increased availability of soil moisture under drip irrigation coupled with fertigation might have led to effective absorption and utilization of nutrients and better proliferation of roots resulting in better canopy growth. The favourable increase in growth attributes in terms of plant height and dry matter accumulation due to drip fertigation was reported by Bhalerao et al., (2011), and Ayyadurai et al., (2014). The plant height under drip irrigation with soil application of nutrients was inferior compared to fertigation. The limited root zone and the reduced amount of mineralization in the restricted wetting zone might be the probable reason for the reduced nutrient availability and reduction in growth of cotton under drip irrigation combined with soil application of fertilizers. Increased growth parameters with 125 per cent recommended $\mathrm{N}$ and $\mathrm{K} \mathrm{ha}^{-1}$ might be due to presence of favourable microclimate to the plants and application of sufficient nutrients in readily available form would have accelerated the proliferation of growth regulators such as auxin (IAA) and cytokinin which in turn stimulated the action of cell elongation and cell division and resulted in increased growth of cotton. Similar findings were reported by Kavitha et al., (2007) in tomato and Anitta (2010) in maize. Fertilizer application through irrigation water takes the nutrients in dissolved state throughout the root zone. The dissolved nutrients have the distribution along the wetting soil volume. This might have resulted in more uptake of nutrients and growth resulting in higher dry matter production. Veeraputhiran (2000), Sathyaprakash (2007), Bhalerao et al., (2011) reported higher dry matter accumulation when fertilizers were applied through fertigation in splits. Nalayani et al., (2012), Gokila (2012) and Ayyadurai et al., (2014) also reported that split application of $\mathrm{N}$ and $\mathrm{K}$ in more split enhanced the dry matter production.

Higher number of sympodia per plant in fertigation of $\mathrm{N}$ and $\mathrm{K}$ splits might be due to higher uptake of nutrients and further vegetative growth of the cotton plant. Veeraputhiran (2000), Sathyaprakash (2007), Avudaithai et al., (2009), Bhalerao et al., (2011), and Gokila (2012) have reported the 
beneficial effect of higher level of $\mathrm{N}$ and $\mathrm{K}$ fertigation on sympodial branches in cotton which indicated that $\mathrm{Bt}$ cotton required more nutrients for enhancing the yield attributes.(Sankarnarayanan et al., 2004).

\section{Yield attributes}

As indicated in Table1,the yield attributing characters like number of bolls picked per plant and seed cotton yield per plant influenced significantly due to split application of recommended dose of nitrogen and potassium $\mathrm{ha}^{-1}$ through fertigation and higher level of RDNK ha ${ }^{-1}$ through fertigation at 125 per cent recommended dose of $\mathrm{N}$ and $\mathrm{K}$ favourably increased these yield attributes than other lower level of fertigation and soil application method of applying fertilizers.However, 75 per cent fertigation and 100 per cent soil application of recommended $\mathrm{N}$ and $\mathrm{K} \mathrm{ha}{ }^{-1}$ were equally effective in enhancing number of picked bolls per plant and seed cotton yield per plant. Average boll weight was found at par among the treatments during the course of investigation. Lower values of all the yield attributing characters were observed at lower levels of 50 per cent fertigation.

The substantial increase in number of picked bolls per plant and seed cotton weight per plant due to higher levels of fertigation than lower level and conventional method was associated with the improvement in various growth attributes viz. plant height, number of sympodial branches, functional leaves, leaf area and dry matter accumulation per plant and its subsequent translocation to sink.

The cumulative effect of these finally improved the number of picked bolls per plant and seed cotton yield per plant, because the ability of cotton crop to produce and support more number of bolls depends on dry matter accumulation and its translocation to sink.
The increase in more number of bolls per plant under higher level of fertigation might be due to enhanced availability and uptake of nutrients to enhance photosynthesis, expansion of leaves and translocation of nutrients to reproductive parts as compared to lower rate of $\mathrm{N}$ and $\mathrm{K}$ given through fertigation and over conventional soil application of fertilizers. Similar advantage of higher level of fertigation of nutrients in improving the number of picked bolls per plant and weight of seed cotton per plant were reported earlier Biwalkar et al., (2005), Bhattoo et al., (2008), Sahadeva Reddy and Aruna (2010), Bhalerao et al., (2011) and Gokila (2012).

\section{Seed cotton yield}

Drip fertigation levels had marked and favourable influence on growth and yield parameters viz. plant height, number of sympodial branches plant-1, leaf area, dry matter production, number of picked bolls per plant and seed cotton yield per plant of cotton during both the years of study. These favourable influences on these parameters were reflected on seed cotton yield due to various treatments. (Table 1).

The perceptible effect of higher levels of fertigation at 125 per cent RDNK ha ${ }^{-1}$ in promoting the growth and yield parameters of the crop had definite say on the final seed cotton yield. The seed cotton yield linearly increased with increasing levels of fertilizers applied through fertigation. Drip fertigation at 125 per cent RDNK ha ${ }^{-1}$ had recorded higher seed cotton yield of $3680 \mathrm{Kg} \mathrm{ha}^{-1}, 3326 \mathrm{Kg}$ $\mathrm{ha}^{-1}$ and $3503 \mathrm{Kg} \mathrm{ha}{ }^{-1}$ during 2011-12 and 2012-13 and pooled mean respectively which was followed by 100 per cent drip fertigation of RDNK ha ${ }^{-1}$ with seed cotton yield of 3362 $\mathrm{Kg} \mathrm{ha}{ }^{-1}, 3030 \mathrm{Kg} \mathrm{ha}^{-1}$ and $3196 \mathrm{Kg} \mathrm{ha}^{-}$ ${ }^{1}$ respectively. 
Table.1 Growth parameters and yield attributes as influenced by various fertigation treatments (Pooled mean of two year)

\begin{tabular}{|c|c|c|c|c|c|c|c|c|c|}
\hline \multirow{2}{*}{ Treatments } & \multirow{2}{*}{$\begin{array}{c}\text { Plant } \\
\text { height } \\
\text { (cm) }\end{array}$} & \multirow{2}{*}{$\begin{array}{c}\text { Dry matter } \\
\text { accumulation } \\
\text { per plant (g) }\end{array}$} & \multirow{2}{*}{$\begin{array}{c}\text { Sympodial } \\
\text { branches } \\
\text { per plant }\end{array}$} & \multirow{2}{*}{$\begin{array}{c}\text { No. of } \\
\text { picked } \\
\text { bolls per } \\
\text { plant }\end{array}$} & \multirow{2}{*}{$\begin{array}{c}\text { Boll } \\
\text { Weight } \\
\text { (g) }\end{array}$} & \multirow{2}{*}{$\begin{array}{c}\text { Yield } \\
\text { per } \\
\text { plant(g) }\end{array}$} & \multicolumn{3}{|c|}{$\begin{array}{c}\text { Seed Cotton Yield } \\
\left(\mathrm{Kgha}^{-1}\right)\end{array}$} \\
\hline & & & & & & & 2011-12 & 2012-13 & Pooled \\
\hline $\begin{array}{l}\mathbf{T}_{1}: \text { DI }+100 \% \text { RDNK soil } \\
\text { application }\end{array}$ & 132.88 & 253.98 & 28.79 & 41.90 & 4.85 & 198.30 & 2740 & 2519 & 2629 \\
\hline $\mathbf{T}_{2}: \mathrm{DF}+50 \% \mathrm{RDNK}$ & 125.65 & 233.29 & 25.44 & 37.27 & 4.68 & 169.70 & 2350 & 2212 & 2281 \\
\hline $\mathbf{T}_{3}: \mathrm{DF}+75 \% \mathrm{RDNK}$ & 135.13 & 259.55 & 29.16 & 44.12 & 4.87 & 208.88 & 2894 & 2620 & 2757 \\
\hline $\mathbf{T}_{4}: \mathrm{DF}+100 \% \mathrm{RDNK}$ & 141.99 & 265.35 & 31.64 & 50.79 & 4.90 & 242.54 & 3362 & 3030 & 3196 \\
\hline $\mathbf{T}_{5}: \mathrm{DF}+125 \% \mathrm{RDNK}$ & 148.15 & 285.61 & 35.26 & 55.43 & 4.92 & 266.28 & 3680 & 3326 & 3503 \\
\hline S. E. $(\mathrm{m}) \pm$ & 1.97 & 6.50 & 0.82 & 1.37 & 0.11 & 6.69 & 102 & 95 & 93 \\
\hline C. D. at $5 \%$ & 6.08 & 19.04 & 2.53 & 4.12 & NS & 20.41 & 315 & 294 & 287 \\
\hline
\end{tabular}

Table.2 Nutrients uptake $\left(\mathrm{kg} \mathrm{ha}^{-1}\right)$ as influenced by different fertigation treatments in cotton (Pooled mean)

\begin{tabular}{|c|c|c|c|c|}
\hline \multirow[t]{2}{*}{ Treatments } & \multicolumn{3}{|c|}{ Nutrient Uptake $\left(\mathrm{Kgha}^{-1}\right)$} & \multirow{2}{*}{$\begin{array}{c}\text { Total Uptake } \\
\left(\mathrm{Kgha}^{-1}\right)\end{array}$} \\
\hline & $\mathrm{N}$ & $\mathrm{P}$ & $\mathrm{K}$ & \\
\hline $\mathbf{T}_{1}:$ DI +100\% RDNK soil application & 113.59 & 31.72 & 82.81 & 228.12 \\
\hline $\mathbf{T}_{2}: \mathrm{DF}+50 \% \mathrm{RDNK}$ & 96.36 & 26.96 & 72.98 & 196.30 \\
\hline $\mathbf{T}_{3}: \mathrm{DF}+75 \% \mathrm{RDNK}$ & 119.47 & 32.74 & 84.59 & 236.80 \\
\hline $\mathbf{T}_{\mathbf{4}}: \mathrm{DF}+100 \% \mathrm{RDNK}$ & 136.01 & 35.13 & 97.60 & 268.74 \\
\hline $\mathbf{T}_{5}: \mathrm{DF}+125 \% \mathrm{RDNK}$ & 152.07 & 38.43 & 110.92 & 301.42 \\
\hline S. E. $(\mathrm{m}) \pm$ & 4.26 & 1.05 & 2.90 & -- \\
\hline C. D. at $5 \%$ & 13.12 & 3.23 & 8.92 & -- \\
\hline
\end{tabular}


Drip fertigation at higher level of 125 per cent fertigation recorded an increased yield of 25.55 per cent and 24.26 per cent over conventional soil application during the year 2011-12 and 2012-13 respectively. Increased nutrient availability and absorption by the crop at the optimum moisture supply coupled with frequent and higher nutrient supply by fertigation and consequent better formation and translocation of assimilates from source to sink might have increased seed cotton yield under fertigation. Fertilizer application of 100 per cent $\mathrm{N}$ and $\mathrm{K}$ through drip increased yield significantly over 100 per cent NPK through soil and the increase was $567 \mathrm{kgha}^{-1}$ seed cotton yield which was 17.74 per cent increase over pooled of two years indicating benefit of drip for better utilization of applied nutrients. The results are in conformity with the findings of Shanmugham et al., (2007), Hadole et al., (2012) and Nalayani et al., (2012).

Drip fertigation at 75 per cent RDNK ha ${ }^{-1}$ recorded comparable yield with 100 per cent recommended dose of fertilizers applied through soil by conventional method during both the years of study and also pooled of two years indicating 25 per cent fertilizer saving through fertigation when compared to conventional soil application of fertilizers.

The saving of fertilizers might be due to reduction in losses of nutrients through volatilization and leaching and better movement of nutrients under drip fertigation as against soil application of fertilizers as reported by Shilpa Yende (2003) and Pawar et al., (2013). The seed cotton yield under drip irrigation with soil application of recommended dose of $\mathrm{N}$ and $\mathrm{K}$ was significantly lower and inferior over higherlevel of drip fertigation. Soil application of fertilizers under drip irrigation might have restricted the mineralization of nutrients and enhanced the losses due to volatilization and this might be the probable reason for the lower yield under drip irrigation with soil application of nutrients. Nalayani et al., (2012), Singh et al., (2012) and Ayyadurai et al., (2014) also reported that drip fertigation had greater advantages and increased seed cotton yield as compared to broadcast application of fertilizer nutrients.

\section{Nutrients uptake}

As indicated in Table 2, it was observed that, different fertigation levels and soil application method showed significant influence on nutrients ( $\mathrm{N}, \mathrm{P}$ and $\mathrm{K}$ ) uptake by plant. The nutrient uptake was favourably increased with higher level of fertigation compared with lower levels and soil application method. Higher uptake of N, P and K were observed at 125 per cent levels of $\mathrm{N}$ and $\mathrm{K}$ fertigation. Progressive increase in applied level of $\mathrm{N}$ and $\mathrm{K}$ correspondingly increased the nutrient uptake and lower uptake was noticed at lower level of fertigation (50 per cent) However, drip fertigation at 75 per cent RDNK ha ${ }^{-1}$ and soil application method $\left(\mathrm{T}_{1}\right)$ were comparable in respect of $\mathrm{N}, \mathrm{P}$ and $\mathrm{K}$ uptake. The concentration and availability of various nutrients in the soil for plant uptake depends on soil solution phase which is mainly determined by soil moisture availability. The higher available soil moisture provided due to continuous water supply at alternate days under drip irrigation led to higher availability of nutrients in the soil and thereby increased the nutrient uptake under drip fertigation levels in splits was the result of increased biomass production due to continuous availability of water and nutrients to the crop.

An application of $\mathrm{N}$ given through fertigation not only stimulated vegetative growth and foraging capacity of roots, but also encouraged the absorption and translocation of more nutrients under higher drip fertigation levels. Due to improved growth characters, 
the plants tend to take more nutrients from the soil since it was available nearer to root zone at required level. Reducing the fertilizer dose resulted in reduced availability of nutrients which might be the reason for lower uptake of nutrients by crop at lower doses of fertilizers as indicated in the present study. In conventional method of soil application of fertilizers, application of large quantity of fertilizers as a single dose resulted in higher volatilization losses of nutrients and resulted lower the availability of nutrients during later growth stages of crop.

This might be the reason for lower uptake of nutrients by crop, when fertilizers are applied by conventional method. Further application of nutrients in more number of splits through drip irrigation resulted in minimum or no wastage of nutrients either through deep percolation or volatilization ultimately led to higher uptake of all the nutrients as reported by Raskar (2004).Higher nutrient uptake with higher level of fertigation over soil application was also reported by Veeraputhiran et al., (2005), Bhalerao et al., (2011), Pawar et al., (2013) and Ayyadurai et al., (2014). The similar trend was observed in respect of total uptake as observed in case of individual nutrient uptake.

On the basis of two years data, it could be concluded that application of 125 per cent recommended dose of $\mathrm{N}$ and $\mathrm{K}$ through fertigation ( $\mathrm{P}$ as basal) was found better to register significantly higher growth and yield attributes and seed cotton yield compared to lower levels of $\mathrm{N}$ and $\mathrm{K}$ fertigation and soil application method. Also it is concluded that, drip fertigation at 75 per cent recommended dose of $\mathrm{N}$ and $\mathrm{K} \mathrm{ha}^{-1}$ was comparable in relation to growth, yield and uptake of nutrients compared to 100 per cent RDNK ha 1 applied through soil by conventional method indicating 25 per cent fertilizer saving through fertigation in $\mathrm{Bt}$ cotton.

\section{References}

Anitta, F.S., 2010. Effect of drip fertigation in intensive maize (Zea mays) based intercropping system. Ph.D. Thesis, TNAU, Coimbatore.

Ayyadurai P., and P. Manickasundaram, 2014. Growth, nutrient uptake and seed cotton yield as influenced by foliar nutrition and drip fertigation in cotton hybrid. International J. Agric. Sci. 10(1):276-279.

Bhalerao, P. D., G. S. Gaikwadand S. R. Imade, 2011. Productivity and nutrient uptake of Bt-cotton (Gossypiumhirsutum) as influenced by precision in application of irrigation and fertilizer.Indian Journal of Agronomy. 56(2): 150-153.

Bhattoo, M.S., Dev Raj, K.S.Nirania and P.P.Jain.2008.Effect of different levels of irrigation and fertilizers through drip on productivity of Bt cotton. Abstract of paper In: National Symposium on "BtCotton: Opportunities and Prospects" Oral presentation.

Gokila, J., 2012. Optimizing irrigation and fertigation schedule under drip fertigation system in Bt cotton.Ph.D. (Agri.) Thesis. (Unpublished), Tamil Nadu Agricultural University, Coimbatore.

Hadole, S.S., G.J. Bhagat, A.H. Nagone and V.R. Thakur, 2012. Nutrient management through drip system of irrigation in cotton. PKV. Res. J. 36(2):52-55.

Kavitha, M., S. Natarajan; L. Pugalendhi and N. Meenakshi, 2007.Yield and quality of tomato under shade and open conditions. Research on Crops. 8(3):651-655.

Mahmood-ul-Hasan; Taj Muhammad and Muhammad Nasrullah, 2003. Cotton response to split application of nitrogen fertilizer. Asian J. Plant Sciences. 2(6):457-460. 
Nalayini, P., S. Paul Raj and K. Sankaranarayanan, 2012. Drip fertigation of major, secondary and micronutrients for enhancing the productivity of extra long staple Bt cotton.J. Cotton Res. Dev. 26 (2): 186189.

Nasarabad, G.G., Rajput, T.B.S. and Patel, N. 2013. Soil water distribution and simulation under subsurface drip irrigation in cotton (Gossypium hirsutum). Indian Journal of Agril. Sciences. 83(1):63-70

Pawar D.D., S.K.Dingre, B.D.Bhakre and U.S.Surve, 2013.Nutrient and water use by Bt. cotton (Gossypiumhirsutum) under drip fertigation.Indian J. Agronomy.58 (2): 237-242.

Raskar, B.S., 2004. Effect of irrigation methods, fertilizer levels and green manuring on yield and nutrient balance in summer cotton. J. Cotton Res. Dev. 18(2): 180-183.

Sahadeva Reddy and E. Aruna, 2010. Effect of doses and split application of nutrients through fertigation in Btcotton (Gossypiumhirsutum L.).J. Cotton Res. Dev. 24 (1): 59-63.

Sathyaprakash, D., 2007. Drip fertigation and bio fertigation studies on cotton hybrid. M.Sc. (Agri.) Thesis (Unpub.) Tamil Nadu Agricultural University, Coimbatore.

Satyanarayana Rao, and Setty, R.A., 2002.
Response of hybrid cotton to levels and times of nitrogen and potash application under irrigated condition.J.CottonRes.Dev. 16:188-189. Shanmugham, P. M., R. K. Selavaraj, K. Ramamoorthy, T. Chideshwari and P. Subbian, 2007. Performance evaluation of drip irrigation and fertigation on the yield and water use efficiency of cotton. National Academy of Agricultural Science. $\quad 8^{\text {th }}$ Agricultural $\quad$ Science Congress, February 15-17, held at TNAU, Coimbatore. Pp 131-132.

Shilpa Yende, B., N.D. Ahatonde, and J.S. Vyas, 2003. Response of pre-monsoon hybrid cotton to NPK fertilization through fertigation.Annals of Plant Physiology.17(2):211-212.

Singh Jagvir, Babar Shilpa, Deshmukh Rachana, P.R. Bharmbe and R.B. Singandhupe, 2012. Drip fertigation effect on yield, water use efficiency and economics of $\mathrm{Bt}$ cotton in semi-arid region. PKV. Res. J. 36(2):52-55.

Veeraputhiran, R., 2000. Drip fertigation studies in hybrid cotton. Ph.D. Thesis (Unpub.), TNAU, Coimbatore.

Veeraputhiran, R., and C. Chinnusamy, 2005 . Production potential, water and nitrogen use efficiency of hybrid cotton as influenced by drip irrigation and nitrogen fertigation. J. Cotton Res. Dev. 19(1):61-65.

\section{How to cite this article:}

Sanjay Kakade, Vilas Bhale, Jayant Deshmukh and Sudhir Wadatkar. 2017. Growth, Nutrient Uptake and Seed Cotton Yield As Influenced By Split Application of Nutrients through Fertigation in Bt Cotton. Int.J.Curr.Microbiol.App.Sci. 6(9): 2982-2990. doi: https://doi.org/10.20546/ijcmas.2017.609.366 